\title{
ANALISIS CERPEN “ROBOHNYA SURAU KAMI" KARYA A.A. NAVIS DALAM PERSPEKTIF POSMODERNISME LINDA HUTCHEON
}

\author{
Rudi Ekasiswanto \\ Email: rudiekasiswanto@ugm.ac.id
}

Staf Pengajar Bahasa dan Sastra Indonesia, Departemen Bahasa dan Sastra

Fakultas Ilmu Budaya Universitas Gadjah Mada, Yogyakarta

\begin{abstract}
This study aims to provide sympathetic insight for whom are interested in short stories in Indonesia through the perspective of Linda Hutcheon historical postmodernism. Through this research, we can find a description of story facts and the ideas of the author that are realized through the center and the periphery, along with the contextualization aspects of the short story A.A. Navis' Robohnya Surau Kami to nowadays society. This research also contributes to literary works appreciation to educational institutions, academics, the society of literary enthusiasts, and the wider community in the form of short story research with the perspective of Linda Hutcheon's postmodernism so that it is expected to increase the quantity of practice in postmodernism studies. The methodology used in short story Robohnya Surau Kami using Linda Hutcheon's postmodernist theory is a descriptive method of analysis, by describing the facts which are then analyzed. The analysis does not merely describe but also gives sufficient understanding and explanation. Robohnya Surau Kami by A. A. Navis is a monumental work A. A. Navis containing religious elements. In his work, A. A. Navis presents inner experiences about the concept of religious life of small communities in Indonesia. This short story is an outstanding and popular work as it is consider as a rare religious literature; AA Navis does not merely tell about worship and devotion to God, but also humanitarian values in Indonesia loaded with caring and tolerance so that it is necessary to trace the facts of the story in the short story, identify the center and the periphery that triggers conflict, and the implications of its contextualization of society in the present.
\end{abstract}

Keywords: postmodernism, postmodern fiction, story facts, fiction elements, center and periphery, contextualization 


\section{PENDAHULUAN}

Istilah posmodernisme muncul pada tahun 1926 sebagai judul buku dan mulai banyak digunakan di dunia Barat pada tahun 1930-1940. Posmodernisme berfokus pada transformasi penting yang terjadi di masyarakat dan kebudayaan kontemporer (Sarup, 2003: 228). Menurut McHale (1991: 4), posmodernisme adalah istilah yang acuannya tidak ada karena ia adalah suatu konstruksi. Meski demikian, McHale (1991: 5) menekankan bahwa posmodernisme tidak melulu terjadi 'setelah' modernisme, namun lebih kepada 'dari' modernisme. Menurut Hutcheon (2004: 1), posmodernisme membangun ideologi yang kontradiktif, tetapi tidak oposisional.

I offer instead, then, a specific, if polemical, start from which to operate as a cultural activity that can be discerned in most art forms and many currents of thought today, what I want to call postmodernism is fundamentally contradictory, resolutely historical, and inescapably political. (Hutcheon, 1988: 4)

Dalam karya sastra posmodernisme, faktor otonom menjadi hal yang diragukan. Karya posmodernisme menjunjung sifat intertekstual dalam pembentuknya, sehingga terdapat konstruksi historiografi dalam sebuah fiksi posmodern. Kontradiksi posmodernisme termanifestasi pada konsep "keberadaan masa lalu" yang bertujuan untuk membentuk karya yang kritis (Hutcheon, 1988:4). Dalam usahanya, penulis akan mengungkapkan gagasan-gagasannya baik secara implisit maupun eksplisit. Beyley (dalam Hutcheon, 1988: 57) mengungkapkan bahwa siapapun yang menulis sebuah karya pasti memiliki ide yang jelas mengenai apa yang baik dan buruk dalam kehidupan. Melalui ide-ide yang diwujudkan inilah, penulis akan menunjukkan keberpihakannya terhadap dunia. Hal ini dapat diketahui dengan menelusuri kontekstualisasi antara karya dengan kondisi sosial masyarakat.

Pada aplikasinya dalam bidang kesusasteraan, teori posmodernisme lebih sering digunakan untuk mengkaji karya-karya yang dianggap baru ataupun mendukung modernitas. Melalui teori posmodernisme, karya-karya tertentu ditelaah dan dipandang perspektif posmodern-nya sehingga menjadi fiksi posmodern. Namun sebagai perkembangan dari modernisme, posmodernisme juga dapat digunakan untuk mengkaji karya-karya yang telah terbit dalam kurun waktu yang lama. Salah satunya adalah cerpen berjudul Robohnya Surau Kami karya Ali Akbar Navis.

Robohnya Surau Kami adalah karya monumental A.A. Navis yang terbit dalam kumpulan cerpen pada tahun 1965 dan masih dikenal hingga sekarang. Pada masa tersebut, karya sastra yang lahir cenderung menampakkan aspek-aspek posmodernisme (Prihatmi, 1999), yakni menampilkan peristiwa yang seringkali berada di luar logika pada umumnya. Pada masa tersebut, Robohnya Surau Kami pun dinilai 'berada di luar logika umum' sebab ia menceritakan peristiwa yang 'mengada-ada dan tidak nyata'. Meskipun demikian, cerpen tersebut tetap dapat diteliti aspek posmodernitas-nya sebab ia memiliki relevansi dengan kehidupan sosial masyarakat; Robohnya Surau Kami dinilai menyajikan pandangan yang memiliki pengaruh terhadap manusia sebab ia menjelaskan hal-hal yang dihindari sebagian besar umat beragama, yakni pertanyaan dan konstruksi mengenai dosa dan pahala, hari akhir dan akhirat, serta ketuhanan. 
Cerpen Robohnya Surau Kami karya A. A. Navis menceritakan tentang seorang penjaga surau yang meradang akibat mendengar cerita dari seorang pembual tentang kejadian di akhirat kelak. Dikisahkan oleh si pembual, bahwa Tuhan lebih menyukai orang-orang yang tidak hanya fokus beribadah sepanjang hidupnya, tetapi juga menjalankan perintah-Nya untuk menyayangi sesama, melindungi keluarga, mencintai alam, bekerja, dan sebagainya. Si kakek penjaga surau yang memang menghabiskan hidupnya untuk merawat surau dan beribadah kepada Tuhan pun akhirnya bunuh diri.

Dalam proses kreatifnya, A.A. Navis dikenal selalu memberikan efek getir pada cerita-ceritanya untuk membahas mengenai ironi yang ada di dunia, terutama di negeri ini. Dari cara penulisan itu, dapat diketahui apa yang menjadi maksud pengarang sebenarnya. Hal ini disebabkan oleh proses penulisan karya yang sangat dipengaruhi oleh keadaan yang sedang berlaku di sekitar seorang penulis. Penulis yang peka akan terangsang intuisi kebahasaannya untuk melihat dan menerjemahkan apa yang terjadi menjadi bahan olahan untuk kemudian diproses menjadi sebuah kisah yang bahkan bisa tak pernah menampakkan ide dasar penulis secara gamblang, namun harus dianalisis oleh pembaca, dengan kata lain dituliskan secara implisit.

Hal ini senada dengan yang dilontarkan Teeuw (1988), bahwa sastra Indonesia lahir pada tahun 1920 dengan latar belakang sosial politik, oleh sebab itu sastra menjadi media bagi para pemuda untuk mulai menyuarakan pikirannya. Latar belakang itu tampak dari cara A.A. Navis menggunakan unsur kedaerahan dalam cerita-ceritanya. Menurut Goodman (1977), ...the abstract literary elements are to be found, not in the signications and their associations, but in the means of signifying; they are not the denotations and connotations, but the parts of speech.

Jadi, elemen abstrak kesusasteraan dapat ditemukan, tidak secara signifikan dan dalam asosiasi-asosiasi tertentu, tapi memiliki makna yang menandakan; elemen abstrak tersebut bukanlah denotasi maupun konotasi, melainkan bagian dari cara berbicara. Dari sanalah sastra yang cenderung abstrak juga diminati oleh sebagian orang. Demikian juga yang terdapat dalam cerpen Robohnya Surau Kami. Daripada menceritakan secara eksplisit kebobrokan moral serta sosial yang mengimpitnya, A.A. Navis memilih untuk meracik ceritanya dengan sederhana, khas, dan penuh makna. Ia tak mendiskreditkan pihak tertentu, tapi mampu melayangkan kritik secara tepat sasaran kepada umat manusia secara keseluruhan. Hal ini pun tak membuat cerpennya berbatas pada diskursi didaktif semata. Sebaliknya, A.A. Navis menyiratkan ironi yang bahkan dapat menjembatani pikiran siapa saja. Daripada disebut mengkritik umat beragama atau cara beragama, A.A. Navis bisa dibilang menonjolkan tuntunan hidup yang ingin disampaikan dan dihayati bersama. Dengan demikian, dapat diketahui bahwa cerpen Robohnya Surau Kami juga termasuk sebagai fiksi posmodern sesuai dengan pendapat Hutcheon (1988: 41) berikut.

The more complex and more overt discursive contextualizing of postmodernism goes one step beyond this auto-representation and its demystifying intent, for it is fundamentally critical in its ironic relation to the past and the present. This is true of 
postmodern fiction and architecture, as it is of much contemporary historical, philosophical, and literary theoretical discourse today.

Menurut Hutcheon, fiksi posmodern terbebas dari representasi otomatis dan usaha-usaha deskriptif belaka. Ia secara fundamental kritis dalam relasi ironinya terhadap masa lalu dan masa depan. Dalam hal ini, Robohnya Surau Kami memiliki kecenderungan untuk mengatasi representasi otomatis tersebut dan sebaliknya, ia mengarahkan bentuk yang terlepas dari nostalgia. Hal ini dapat terlihat dari penggambaran narasi keseluruhan cerita yang dituturkan dari sudut pandang tokoh 'aku' terhadap pembaca yang diwakilkan sebagai 'Tuan'.

Kalau beberapa tahun yang lalu Tuan datang ke kota kelahiranku dengan menumpang bis, Tuan akan berhenti di dekat pasar. Maka kira-kira sekilometer dari pasar akan sampailah Tuan di jalan kampungku (Navis, 1965:140).

Pada penggalan cerpen di atas, dapat diketahui bahwa tokoh 'aku' memperkenalkan segala unsur dalam ceritanya dengan gamblang. Ia mendapati diri sebagai narator yang menyadari keberadaan pembacanya dan secara tidak langsung menunjukkan urgensi isi pesan yang dibawanya. Pemilihan sudut pandang ini dijelaskan Hutcheon (1988:45) sebagai berikut.

In its contradictions, postmodernist fiction tries to offer what Stanley Fish (1972, xiii) once called a "dialectical" literary presentation, one that disturbs readers, forcing them to scrutinize their own values and beliefs, rather than pandering to or satisfying them. But as Umberto Eco has reminded us, postmodern fiction may seem more open in form, but constraint is always needed in order to feel free (in Rosso 1983, 6). This kind of novel self consciously uses the trappings of what Fish calls "rhetorical" literary presentation (omniscient narrators, coherent characterization, plot closure) in order to point to the humanly constructed character of these trappings-their arbitrariness and conventionality.

Fiksi posmodern mencoba menawarkan presentasi sastra 'dialektis' yang terkesan mengganggu pembaca dan memaksa mereka untuk meneliti nilai-nilai dan keyakinan yang mereka anut, daripada sekadar menjadi pemuas mereka. Meskipun fiksi posmodern tampak lebih terbuka, selalu terdapat pengikat yang membuat kita menyadari pentingnya menjadi bebas. Dengan demikian fiksi posmodern secara sadar menggunakan apa yang disebut Fish sebagai presentasi sastra 'retoris' (narator mahatahu, karakterisasi yang koheren, penutupan alur) untuk menunjukkan karakter yang dibangun secara manusiawi-baik kesewenang-wenangan dan konvensionalitas mereka. Menurut Hutcheon (1988:45) hal ini merupakan salah satu eksploitasi kontradiktif posmodern dan subversi dari aspek-aspek fiksi realis maupun modernis. Dari penjabaran di atas, dapat kita ketahui bahwa Robohnya Surau Kami memuat ciri fiksi posmodern. Keberadaannya bukan sebagai pemuas golongan ekstrem tertentu, sebaliknya ia memuat nilai-nilai kebersamaan dan kearifan yang umum kita kenali dalam masyarakat daerah Indonesia yang menjunjung kekerabatan. Ia juga dapat disebut sebagai posmodern sebab meninggalkan baik aspek fiksi realis maupun modernis. 
Hal ini cukup menarik sebab Robohnya Surau Kami selama ini lebih dikenal sebagai karya yang berlatarkan religiusitas. Dewasa ini, topik tentang karya sastra dengan nuansa keagamaan yang kental menjadi salah satu isu yang digemari khalayak luas, terutama berkenaan dengan merenggangnya ikatan toleransi antarwarga Indonesia. Secara teori, hal ini dapat dijelaskan sebagai berikut.

Menurut Heryanto (2018: 73), agama dapat menawarkan keteduhan bagi orang-orang yang tak mampu secara ekonomi dan politik serta tak memiliki perwakilan atau kuasa dalam meraih keadilan. Bagi orang kaya urban yang kritis terhadap status quo, agama dapat berperan sebagai titik berangkat bagi pembangkangan ketika seluruh jalur yang sah untuk politik resmi sudah ditutup. Bagi mereka yang sedang berkuasa, dikelilingi oleh kemiskinan, korupsi, dan kekerasan yang disponsori oleh negara, ketakwaan dapat membantu memulihkan kecemasan tentang status mereka, mengurangi rasa bersalah, atau menetralkan persepsi publik tentang kerakusan mereka. Lambat laun, hal ini dikenal sebagai identitas religiusitas yang tercermin dalam berbagai produk kehidupan manusia, salah satunya karya sastra.

Belakangan, dengan maraknya peristiwa benturan beragama, penelitian dengan objek sastra religi menjadi kembali diminati. Terutama berkenaan dengan tujuan penciptaan karya sastra dan bagaimana pembaca mampu menerimanya. Herfanda (2008: 132) menyatakan bahwa apa pun orientasi penciptaan karya sastra, karena merupakan sekumpulan sistem tanda yang menyimpan makna, maka ia akan memiliki kemampuan tersembunyi (subversif) untuk mempengaruhi perasaan dan pikiran pembacanya. Hal ini menjadi salah satu kemampatan sastra religi untuk membenahi diri dan menguatkan posisinya sebagai karya sastra yang seharusnya direaksi, diproses, atau dipecahkan. Kreativitas dalam sastra religi diharapkan untuk selalu berada pada jalur yang semestinya, sebisa mungkin tidak menimbulkan kontroversi. Padahal, menurut William (dalam Faruk, 2015: 44), kreativitias merupakan ciri khas sastra, bahkan menyangkut keseluruhan tata kehidupan masyarakat. Setiap pengarang akan menggunakan cipta, rasa, dan karsa dalam berkarya. Begitu pula pembaca, dalam menanggapi karya sastra juga tidak akan lepas dari kejiwaan masing-masing (Denta: 2010).

Oleh sebab itu, hingga kini sastra religi masih sering mengundang polemikpolemik minor dalam lingkungannya. Terutama berkenaan dengan apa yang dianggap benar dan direstui. Hasil yang diperoleh adalah kebenaran yang mempunyai nilai-nilai artistik yang dapat menambah koherensi dan kompleksitas karya tersebut (Wellek dan Werren, 1990:108). Sebab menurut Mangunwijaya (1982:12), religiusitas sendiri lebih melihat apa yang ada dalam diri seseorang dalam menjalankan kewajiban agamanya. Sementara agama, menurut Mangunwijaya (1982:11), menunjukkan kelembagaan kebaktian pada Tuhan dengan hukum-hukum yang resmi. Religiusitas bersifat totalitas individu. Ia mengatasi lebih dari sekadar agama yang diakui secara kolektif dan memiliki keteraturan ketat. Religiusitas lebih bergerak ke tata paguyuban yang khidmat, konsentrasi diri, pasrah sumarah, dan mendengarkan sabda Ilahi dalam hati (Mangunwijaya, 1982:12). Demi membuktikan bahwa religiusitas memiliki dimensi yang lebih luas daripada agama, Glock dan Stark (dalam Djamaluddin dan Nashori, 2001:76), mengungkapkan lima macam dimensi religiusitas, yaitu (1) dimensi keyakinan (ideologi), (2) dimensi peribadatan 
atau praktik agama (ritualistik), (3) dimensi pengalaman, (4) dimensi ihsan (penghayatan), dan (5) dimensi pengetahuan. Dengan demikian, dapat diketahui bahwa karya sastra yang memuat aspek religiusitas memiliki kompleks yang sama dengan aspek-aspek lainnya. Terutama di Indonesia, yang mana memiliki kadarkadar tertentu tentang kapan religiusitas tersebut ditampakkan dan disembunyikan.

Meski demikian, sastra religi masih menjadi salah satu genre yang diminati pembaca. Banyak di antara karya sastra religi tersebut juga mengusung tema modernitas dan menjadi sastra populer seiring dengan munculnya komunitaskomunitas berbasis keagamaan yang merambah dunia kreatif sebagai media dakwah dan ekspresi diri. Hal ini disebabkan kesadaran para penggiat agama tersebut bahwa, seni populer biasanya lebih dapat diakses-seni populer adalah tentang kita dan ada di mana-mana-dan akrab, dia menarik karena dirinya sendiri dan mengungkapkan secara tidak sadar tentang budaya yang diekspresikan (White, 1972). Di balik itu, masih banyak karya sastra religi yang sejak kemunculannya menjadi salah satu tonggak penanda khazanah sastra Indonesia. Karya-karya ini umumnya termasuk dalam sastra serius. Menurut Pujiharto (2010: 21), karya sastra serius adalah karya yang menyajikan pengalaman kemanusiaan namun dengan tingkat kesulitan pemahaman yang lebih tinggi dibanding sastra populer karena sastra serius menggunakan fakta-fakta dan sarana-sarana cerita yang lebih rumit hingga untuk memahami temanya pun harus melewati langkah-langkah analisis yang serius pula. Sehingga dapat dipahami bahwa sastra religi tidak hanya penting bagi masyarakat pada umumnya, tetapi juga berkenaan dengan sumbangsihnya pada kesusasteraan.

Pada tataran inilah, Robohnya Surau Kami menjadi penentu bahwa sastra religi tidaklah singup seperti yang diperkirakan. Sebaliknya, ia dapat dipandang dalam berbagai paradigma dan metode yang menghasilkan berbagai kesimpulan.

Postmodern fiction challenges both structuralist/modernist formalism and any simple mimeticist/realist notions of referentiality. It took the modernist novel a long time to win back its artistic autonomy from the dogma of realist theories of representation; it has taken the postmodernist novel just as long to win back its historicizing and contextualizing from the dogma of modernist aestheticism. (Hutchen, 1988: 52)

Fiksi posmodern menantang formalisme strukturalis/modernis dan gagasan mimesis/realis sederhana tentang referensialitas. Artinya, ia memiliki kecenderungan untuk mengubah apa yang selama ini dipahami sebagai bentuk baku referensi dan bahkan menggunakan bentuk yang sama sekali baru. Referensi tak lagi ditunjukkan terang-terangan dengan catatan kaki, tetapi dilesapkan dalam keseluruhan isi karya. Robohnya Surau Kami yang termasuk novel lama dapat dikatakan menggunakan kembali otonomi artistiknya dari dogma teori representasi realistis untuk menitikberatkan aspek historisasi dan kontekstualisasi. Robohnya Surau Kami, sesuai pandangan Hutcheon (1988: 53), secara paradoks menggunakan dan menyalahgunakan konvensi realisme dan modernisme untuk menantang transparansi mereka dan untuk mencegah penyingkapan terhadap kontradiksi yang membuatnya menjadi fiksi posmodern sebagaimana adanya: historis dan metafiksi, kontekstual dan refleksi diri, selalu menyadari statusnya sebagai wacana, dan sebagai konstruksi manusia. 


\section{PEMBAHASAN: FAKTA CERITA, PUSAT DAN PINGGIRAN}

Aspek-aspek posmodernisme dalam sebuah karya meliputi penggunaan dan penyimpangan fakta ceritanya dalam membangun keseluruhan cerita dan hubungan antara pinggiran dan pusat, antara tertindas dan penindas, serta kontekstualisasi di dalamnya. Peristiwa yang telah terjadi diceritakan ulang dan ditunjukkan sebagai sesuatu yang secara sadar disusun menjadi narasi yang terkonstruksi sedemikian rupa sehingga dapat dipahami oleh pembaca. Hal ini penting sebab dalam fiksi posmodern, penggunaan konsep "keberadaan masa lalu" sama sekali tidak menyangkal eksistensi masa lalu yang riil, tetapi memusatkan perhatian pada tindak pemaksaan tatanan pada masa lalu itu dengan tidak mengodekan strategi penciptaan-makna melalui representasi (Hutcheon, 2004:104). Oleh sebab itu, pengarang dapat hadir melalui keberpihakannya dalam cerita untuk menyampaikan gagasan dari kelompok atau golongan yang diwakilinya. Fakta yang ada dalam karya sastra dapat menyokong keberadaan pengarang melalui suara-suara kepengarangannya, sudut pandang, narator, atau tokoh-tokoh tertentu untuk menyampaikan gagasan-gagasan yang dipandangnya memiliki tingkat kebenaran atas suatu peristiwa. Sehingga dapat dipahami pelajaran penting dari posmodernisme adalah bahwa peneliti tidak diperbolehkan untuk membatasi investigasinya pada teks dan pembaca, melainkan pada proses produksi sebuah karya. Diperlukan lebih dari sekadar teks dan pembaca untuk mengaktifkan proses pemberian makna atas suatu karya agar apa yang disampaikan dalam karya tersebut mendapat pelekatan makna yang sebenar-benarnya.

\section{Fakta Cerita}

Fakta yang terkandung dalam fiksi posmodernisme ialah peristiwa yang dimaknai. Dalam metafiksi historiografis, proses pengubahan peristiwa menjadi fakta melalui penafsiran bukti dokumenter ditunjukkan sebagai proses pengubahan jejak-jejak masa lalu menjadi representasi historiografis (Hutcheon, 2004:89). Dalam fiksi posmodern, terjadi gabungan unsur faktual dan unsur fiktif. Unsur faktual berupa peristiwa masa lalu, sementara unsur fiktif berupa pelaku, plot, fantasi, prophesi, serta pola dari ritme E.M. Forster (dalam Kuntowijoyo, 2006:176). Pendapat Forster tersebut melengkapi pandangan Hutcheon mengenai unsur-unsur pembangun metafiksi historiografi. Bukti dokumenter yang dimaksud Hutcheon berupa teks-teks lain yang telah terlebih dahulu ada dan berperan sebagai referensi, sehingga fiksi posmodernisme umumnya memuat intertekstualitas untuk menunjang cerita. Teks-teks lain yang sudah ada didukung atau didekonstruksi oleh penulis untuk mewujudkan gagasan yang ingin disampaikannya. Miola (2014:13) mengidentifikasikan intertekstualitas menjadi tiga kategori, yakni; kategori pertama, di mana teks sebelumnya muncul secara verbal/tersurat; kategori kedua, di mana pembaca akan mengenali adanya teks lain dalam teks tersebut melalui kekayaan individualnya; dan kategori ketiga, di mana pemberian teks sebelumnya bersifat argumentatif (memuat referensi berlapis sehingga dapat diperdebatkan). Kategori kedua dan ketiga mengindikasikan teks lain yang muncul secara tersirat. Dalam analisis ini, kajian meliputi tipe teks paralogues, yakni teks yang menjelaskan tokoh, sosial, atau makna politis dalam teks lainnya. 
Today, critics can adduce any contemporary text in conjunction with another, without bothering at all about verbal echo, or even imprecise lines of filiation. In some ways the discussion of paralogues departs from past critical practices, bringing new freedom; but, of course, new perils threaten; rampant and irresponsible association, facile cultural generalization, and anecdotal, impressionistic historicizing. (Miola, 2014:23)

Paralogues muncul secara implisit sehingga penelusuran pembaca tidak akan berhenti pada apa yang disampaikan penulis semata. Paralogues membawakan kebebasan bagi setiap penulis untuk mengekspresikan diri tetapi juga memberikan kaitan historis akan setiap karya. Paralogues disebut pula interdiscursivity, yang berarti hubungan antar teks, baik lisan maupun tulisan, berkenaan dengan semua wacana yang terekam dalam budaya yang memiliki kemiripan dan secara ideologi terorganisir (Miola, 2014:23).

Dalam cerpen Robohnya Surau Kami karya A. A. Navis, unsur interdiskursivitas sarat tampak pada bagaimana pengarang mengungkapkan kepercayaan spiritualnya. Hal ini seperti tampak pada penggalan cerita berikut.

"Pada suatu waktu," kata Ajo Sidi memulai, "di akhirat Tuhan Allah memeriksa orang-orang yang sudah berpulang. Para malaikat bertugas di samping-Nya. Di tangan mereka tergenggam daftar dosa dan pahala manusia. Begitu banyak orang yang diperiksa. Maklumlah dimana-mana ada perang." (Navis, 1965: 143)

Sebagaimana yang diceritakan oleh tokoh Ajo Sidi, A. A. Navis menyitir kutipan-kutipan kepercayaan manusia yang beragama Islam tentang suatu peristiwa yang dipercaya akan terjadi di akhirat. Hal ini dapat terjadi sebab umat Islam diwajibkan mengimani apa yang disebut hari akhir dan hari kebangkitan. Seperti yang tertera pada Surah Az-Zumar ayat 68 yang berbunyi, "Dan ditiuplah sangkakala, maka matilah siapa yang di langit dan di bumi kecuali siapa yang dikehendaki Allah. Kemudian dititup sangkakala itu sekali lagi maka tiba-tiba mereka berdiri menunggu (putusannya masing-masing)." Meskipun secara akal pikiran, hal ini tidaklah dapat dijadikan landasan yang logis, tetapi dalam metafiksi historiografi, hal ini dapat diterima sebab memuat budaya (baik lisan maupun tulisan) yang bersifat spiritual dan terorganisir secara ideologi. Dalam Robohnya Surau Kami, unsur ini dominan sebab kerangka yang dibangun A. A. Navis adalah kemasyarakatan dalam umat Islam yang semakin lama semakin memudar.

Jika dalam metafiksi historiografis, fakta adalah peristiwa yang dimaknai, maka dalam Robohnya Surau Kami, A. A. Navis menarik fakta yang ada dalam isu-isu sosial yang berusaha dikemukakannya dan menjelaskannya dengan cara yang terbilang antimainstream, yakni melalu penghakiman pada hari kebangkitan. Metode ini umumnya banyak diterapkan dalam karya sastra religi yang berusaha memberikan kompensasi terhadap segala sesuatu yang dikerjakan manusia melalui janji-janji dan balasan yang setimpal di kehidupan yang 'sesungguhnya'. Meski demikian, lewat Robohnya Surau Kami, A. A. Navis memberikan twist yang tidak terduga dengan memaknai kriteria Tuhan sebagai hal yang tidak biasa. Alih-alih dengan memberikan kenikmatan dan kebahagiaan (yang diwujudkan dalam bentuk surga) kepada orang-orang yang terus-menerus dan selalu beribadah, Tuhan mempertimbangkan nilai-nilai kemanusiaan dengan memberikan pertimbangan bagi 
mereka yang beribadah sesuai dengan yang dikehendakinya. Dalam Robohnya Surau Kami, hal ini dijelaskan Navis melalui "dan Tuhan memeriksa dengan segala sifatNya" (Navis, 1965:143).

"Ya, Tuhanku, tak ada pekerjaanku selain daripada beribadat menyembah-Mu, menyebut-nyebut nama-Mu. Bahkan dalam kasihMu, ketika aku sakit, nama-Mu menjadi buah bibirku juga. Dan aku selalu berdoa, mendoakan kemurahan hati-Mu untuk menginsafkan umat-Mu."

"Lain?"

Haji Saleh tak dapat menjawab lagi. Ia telah menceritakan segala yang ia kerjakan.

Tapi ia insaf, pertanyaan Tuhan bukan asal bertanya saja, tentu ada lagi yang belum di katakannya. Tapi menurut pendapatnya, ia telah menceritakan segalanya. Ia tak tahu lagi apa yang harus dikatakannya. Ia termenung dan menekurkan kepalanya. Api neraka tiba-tiba menghawakan kehangatannya ke tubuh Haji Saleh. Dan ia menangis.

Tapi setiap air matanya mengalir, diisap kering oleh hawa panas neraka itu. (Navis, 1965:144)

\begin{abstract}
Alangkah tercengang Haji Saleh, karena di neraka itu banyak teman-temannya di dunia terpanggang hangus, merintih kesakitan. Dan ia tambah tak mengerti dengan keadaan dirinya, karena semua orang yang dilihatnya di neraka itu tak kurang ibadatnya dari dia sendiri. Bahkan ada salah seorang yang telah sampai empat belas kali ke Mekah dan bergelar syekh pula. Lalu Haji Saleh mendekati mereka, dan bertanya kenapa mereka dinerakakan semuanya. Tapi sebagaimana Haji Saleh, orang-orang itu pun, tak mengerti juga. (Navis, 1965:145)
\end{abstract}

Kedua peristiwa yang diceritakan Navis melalui tokoh Ajo Sidi di atas sesuai dengan bagaimana Alquran mendeskripsikan surga dan neraka serta para penghuninya. Hal ini tampak melalui Surah Albaqarah ayat 81 yang berbunyi, "barangsiapa berbuat dosa dan ia telah diliputi oleh dosanya, mereka itulah penghuni neraka, mereka kekal di dalamnya" dan Surah Attaubah ayat 72 yang berbunyi, "Allah menjanjikan kepada orang-orang yang mukmin, lelaki dan perempuan, (akan mendapat) surga yang dibawahnya mengalir sungai-sungai, kekal mereka di dalamnya, dan (mendapat) tempat-tempat yang bagus di surga 'Adn. Dan keridaan Allah adalah lebih besar; itu adalah keberuntungan yang besar." Oleh sebab itu, Haji Saleh diceritakan ketakutan ketika isyarat bahwa dirinya akan masuk neraka diperjelas dan surga terasa menjauh.

Karya sastra posmodern mengangkat persoalan bagaimana intertekstualitas historis, dokumen atau jejaknya, disatukan ke dalam konteks yang diakui sebagai rekaan atau fiktif, sementara masih mempertahankan nilai dokumenter historisnya (Hutcheon, 2004: 129). Meskipun sebenarnya Alquran bukanlah bukti historis dalam dunia nyata, terutama bagi yang tidak mengimaninya, namun narasi tentang kiamat sebagai akhir dunia dipercaya sebagai fakta yang akan terjadi sehingga memiliki nilai historis, bahkan bagi seluruh umat beragama di dunia.

\title{
Pusat dan Pinggiran
}

Seperti halnya teori sastra lainnya, posmodernisme mempertanyakan humanisme liberal, yakni otonomi, kepentingan, kepastian, otoritas, kesatuan, 
kemutlakan, sistem, pusat, kesinambungan, hirarki, homogenitas, keunikan, keaslian (Hutcheon, 1988:57). Bagi Hutcheon, karya sastra pada umumnya memiliki ketimpangan dan gesekan antar tokoh-tokohnya sehingga wajar jika keberadaannya cenderung mengguncangkan keaslian dan pusat. Dalam usaha-usaha tersebut, terdapat pihak yang berperan sebagai dominan dan ada pula yang berperan sebagai minoritas. Dalam posmodernisme, hal ini disebut sebagai pusat dan pinggiran.

The decentering of our categories of thought always relies on the centers in contests for its very definition (and often its verbal form). The adjectives may vary: hybrid, heterogeneous, discontinous, antitotalizing, uncertain. (Hutcheon, 1988:59)

Dalam bentuk lain, pinggiran dapat berupa persilangan, keberagaman, keterputusan, antitotalitas, dan ketidakpastian. Menurut Owens (dalam Hutcheon, 1988:59), ketika karya sastra posmodern memenuhi perannya, ia tak lagi menyatakan otonomi, swasembada, ataupun kejelasannya, melainkan untuk menarasikan kemungkinan, ketidakcukupan, dan ketidakjelasan. Dalam hal ini, pusat akan dieksploitasi dan dalam batas-batas tertentu, ditumbangkan. Seperti yang diungkapkan Derrida (dalam Hutcheon, 1988:60) bahwa bukan berarti pusat ditiadakan, karena dalam hakikatnya sendiri manusia tidak akan bisa hidup tanpa pusat, sebab pusat adalah fungsi, bukan suatu bentuk maupun realita. Tanpa keberadaan pusat, pinggiran tak akan ada maupun diakui.

Dalam Robohnya Surau Kami, pinggiran ditunjukkan oleh tokoh Kakek Penjaga Surau. Hal ini ditunjukkan melalui penggambaran berikut.

Sebagai penjaga surau, Kakek tidak mendapat apa-apa. Ia hidup dari sedekah yang dipungutnya sekali se-Jumat. Sekali enam bulan ia mendapat seperempat dari hasil pemungutan ikan mas dari kolam itu. Dan sekali setahun orang-orang mengantarkan fitrah Id kepadanya. Tapi sebagai garin ia tak begitu dikenal. Ia lebih di kenal sebagai pengasah pisau. Karena ia begitu mahir dengan pekerjaannya itu. Orang-orang suka minta tolong kepadanya, sedang ia tak pernah minta imbalan apa-apa. Orang-orang perempuan yang minta tolong mengasahkan pisau atau gunting, memberinya sambal sebagai imbalan. Orang laki-laki yang minta tolong, memberinya imbalan rokok, kadang-kadang uang. Tapi yang paling sering diterimanya ialah ucapan terima kasih dan sedikit senyum. (Navis, 1965: 140)

Dalam hidupnya, Kakek digambarkan sebagai orang yang menyerahkan hidupnya kepada Tuhan. Ia sama sekali tak mencari keuntungan, melainkan sibuk beribadah. Kakek bahkan tak pernah memikirkan kehidupan duniawinya. Sebaliknya, ia taat menegakkan perintah Allah dan berusaha menjauhi segala larangan dan perbuatan dosa. Demikian tokoh Kakek begitu dihormati dan dicintai oleh orang-orang kampung. Tak heran apabila tokoh Kakek digambarkan Navis sebagai simbol surau itu sendiri.

Tapi kakek ini sudah tidak ada lagi sekarang. Ia sudah meninggal. Dan tinggallah surau itu tanpa penjaganya. Hingga anak-anak menggunakannya sebagai tempat bermain, memainkan segala apa yang disukai mereka. Perempuan yang kehabisan kayu bakar, sering suka mencopoti papan dinding atau lantai di malam hari. Jika Tuan datang sekarang, hanya akan menjumpai gambaran yang mengesankan suatu kesucian yang bakal roboh. Dan kerobohan itu kian hari kian cepat berlangsungnya. (Navis, 1965:140) 
Judul Robohnya Surau Kami, secara tidak langsung menunjukkan bagaimana sebenarnya konstruksi pikiran Kakek (begitu pula dengan manusia pada umumnya dan juga sebuah surau) begitu rapuh dan dapat digerogoti oleh suatu ide yang baru. Dalam hal ini, Navis mengungkapkan tentang bagaimana 'beribadah' seharusnya dilakukan dan untuk itu, tentu saja kita perlu menghancurkan konstruksi 'surau' yang tradisional dan digambarkan oleh pemikiran Kakek. Bagaimanapun juga, lamakelamaan tradisi spiritual kita pun akan berubah. Hal ini menunjukkan bahwa meski kehidupannya selalu tegak lurus dengan Yang Maha Kuasa, nampaknya tokoh Kakek menyimpan rasa getir yang disimpannya sendiri. Sekian tahun hidup seorang diri dan beribadah, ia akhirnya menumpahkan kekesalannya begitu seseorang bernama Ajo Sidi menceritakan kisah yang dianggapnya mengusik hidupnya.

Maka aku ingat Ajo Sidi, si pembual itu. Sudah lama aku tak ketemu dia. Dan aku ingin ketemu dia lagi. Aku senang mendengar bualannya. Ajo Sidi bisa mengikat orang-orang dengan bualannya yang aneh-aneh sepanjang hari. Tapi ini jarang terjadi karena ia begitu sibuk dengan pekerjaannya. Sebagai pembual, sukses terbesar baginya ialah karena semua pelaku-pelaku yang diceritakannya menjadi model orang untuk diejek dan ceritanya menjadi pameo akhirnya. Ada-ada saja orang-orang di sekitar kampungku yang cocok dengan watak pelaku-pelaku ceritanya. (Navis, 1965:141)

Tokoh Ajo Sidi dalam Robohnya Surau Kami mencerminkan pusat. Melalui cerita-ceritanya, ia menerapkan kontrol perilaku dalam kehidupan bermasyarakat di kampung tempatnya tinggal. Meski dikenal sebagai pembual, Ajo Sidi mampu menarik orang-orang untuk benar-benar terlarut dalam ceritanya. Hal ini contohnya ditampakkan pada bagaimana ia bisa membuat Kakek begitu bersedih hati melalui sebuah cerita saja. Ajo Sidi tak pernah mengutuk Kakek secara langsung, namun melalui ceritanya ia memberikan pandangan dan keberpihakan yang jelas terhadap bagaimana Kakek menjalani hidup. Dalam hal ini, Ajo Sidi menggunakan ceritanya sebagai sindiran bagi perilaku Kakek yang dianggapnya terlalu lurus dan hanya memprioritaskan Tuhan. Berbeda dengan Kakek yang dipenuhi rasa sentimen, Ajo Sidi bersikap pragmatis. Hal ini tampak pada penggalan cerpen berikut.

Aku cari Ajo Sidi ke rumahnya. Tapi aku berjumpa dengan istrinya saja. Lalu aku tanya dia.

"Ia sudah pergi," jawab istri Ajo Sidi.

"Tidak ia tahu Kakek meninggal?"

"Sudah. Dan ia meninggalkan pesan agar dibelikan kain kafan buat Kakek tujuh lapis."

"Dan sekarang," tanyaku kehilangan akal sungguh mendengar segala peristiwa oleh perbuatan Ajo Sidi yang tidak sedikit pun bertanggung jawab, "dan sekarang kemana dia?"

"Kerja."

"Kerja?" tanyaku mengulangi hampa.

"Ya, dia pergi kerja." (Navis, 1965:149-150)

Tokoh Ajo Sidi seolah tidak pernah benar-benar memedulikan efek yang ditimbulkan oleh perilakunya sehingga menganggap meninggalnya Kakek merupakan hal yang biasa. Ia tak mengacuhkan fakta bahwa Kakek sangat jengkel 
terhadapnya beberapa hari belakangan dan tak sedikitpun meminta maaf terhadap apa yang diceritakannya itu. Ia merupakan simbolisasi dinamika jaman yang terus berubah, tak peduli dengan apa yang digerusnya selama itu memuat tujuan akhir yang ingin dicapai. Hal ini diceritakan oleh tokoh aku sebagai berikut.

Secepat anak-anak berlari di dalamnya, secepat perempuan mencopoti pekayuannya.

Dan yang terutama ialah sifat masa bodoh manusia sekarang, yang tak hendak memelihara apa yang tidak dijaga lagi. Dan biang keladi dari kerobohan ini ialah sebuah dongengan yang tak dapat disangkal kebenarannya. Beginilah kisahnya. (Navis, 1965:140-141)

Dalam penggalan cerpen di atas, tokoh aku menunjukkan akibat dari keahlian Ajo Sidi bersilat lidah tanpa mempertimbangkan lebih jauh efek yang akan ditimbulkannya bagi kehidupan seorang garin maupun keberlangsungan umat muslim. Meski demikian, tokoh aku pun diam-diam menyetujui pendapat Ajo Sidi. Meski digambarkan sebagai tokoh netral yang mampu menjawab dan melintasi permasalahan sudut pandang, tokoh aku menceritakan bagiamana sikap Kakek yang kaku terutama dalam menanggapi segala sesuatu berakhir dengan kerugian Kakek sendiri. Sebaliknya, ia bersimpati kepada Kakek karena baginya, lebih mudah menghadirkan penghiburan daripada mengusik prinsip hidup Kakek yang selama ini bersahaja. Tokoh aku berpendapat bahwa apabila Ajo Sidi tidak membualkan cerita tersebut, Kakek tetap baik-baik saja.

Robohnya Surau Kami memuat cerita berlapis. Pangkal segala permasalahan dalam cerpen ini ialah cerita bualan Ajo Sidi tentang bagaimana haji yang taat beribadah bernama Haji Saleh dihisab di akhirat kelak. Cerita inilah yang membuat Kakek gusar hingga akhirnya bunuh diri. Cerita ini juga memiliki pusat dan pinggirannya sendiri. Dalam hal ini, pusat digambarkan oleh Tuhan dan malaikat, sementara pinggiran diwujudkan dalam bentuk Haji Saleh dan kawan-kawannya sesama orang yang rajin beribadah.

Alangkah tercengang Haji Saleh, karena di neraka itu banyak teman-temannya di dunia terpanggang hangus, merintih kesakitan. Dan ia tambah tak mengerti dengan keadaan dirinya, karena semua orang yang dilihatnya di neraka itu tak kurang ibadatnya dari dia sendiri. Bahkan ada salah seorang yang telah sampai empat belas kali ke Mekah dan bergelar syekh pula. Lalu Haji Saleh mendekati mereka, dan bertanya kenapa mereka dinerakakan semuanya. Tapi sebagaimana Haji Saleh, orang-orang itu pun, tak mengerti juga. "Bagaimana Tuhan kita ini?" kata Haji Saleh kemudian, "bukankah kita disuruh-Nya taat beribadat, teguh beriman? Dan itu semua sudah kita kerjakan selama hidup kita. Tapi kini kita dimasukkan-Nya ke neraka." (Navis, 1965:145)

Pada penggalan cerpen Robohnya Surau Kami di atas, Haji Saleh mengumpulkan orang-orang yang dikenalnya rajin beribadah dan dimasukkan ke neraka. Ia mulai mempertanyakan keadilan Tuhan. Dengan teguh ia mempercayai keyakinannya, bahwa segala amal perbuatannya takkan berdusta dan sebenarnya ia berhak berada di surga sebab tak sedikitpun ia berhenti memuja Tuhan di masa hidupnya. Maka hal ini membuatnya pongah dan sombong. Daripada penghakiman Tuhan, ia lebih mempercayai perhitungannya sendiri yang dilandasi keserakahan serta rasa pamrih.

Haji Saleh yang menjadi pemimpin dan juru bicara tampil ke depan. Dan dengan suara yang menggeletar dan berirama rendah, ia memulai pidatonya: “ $\mathrm{O}$, Tuhan 
kami yang Mahabesar. Kami yang menghadap-Mu ini adalah umat-Mu yang paling taat beribadat, yang paling taat menyembahmu. Kamilah orang-orang yang selalu menyebut nama-Mu, memuji-muji kebesaran-Mu, mempropagandakan keadilan-Mu, dan lain-lainnya. Kitab-Mu kami hafal di luar kepala kami. Tak sesat sedikitpun kami membacanya. Akan tetapi, Tuhanku yang Mahakuasa setelah kami Engkau panggil kemari, Engkau memasukkan kami ke neraka. Maka sebelum terjadi hal-hal yang tak diingini, maka di sini, atas nama orang-orang yang cinta pada-Mu, kami menuntut agar hukuman yang Kaujatuhkan kepada kami ke surga sebagaimana yang Engkau janjikan dalam Kitab-Mu." (Navis, 1965:146-147)

Meski merasa bahwa dirinya adalah korban dari kesalahan Tuhan, Haji Saleh tetap menggunakan metode protes yang santun dan terhormat. Ia mengakui kebesaran Tuhan dan beribadah kepada Tuhan sepenuh hati selama masa hidupnya. Penggalan cerpen di atas menunjukkan sikap inferior Haji Saleh. Kendatipun ia merasa bahwa dirinya selayaknya masuk surga sebab ia tak kurang-kurang dalam beribadah, ia tetap merendah dan menuntut janji Tuhan dengan cara yang dianggapnya diplomatis. Hal ini mencerminkan pinggiran, yang sebagaimanapun kuatnya ia berusaha, pusat yang akan menentukan segalanya. Pusat dalam cerita ini digambarkan sebagai pusaran kosmis yang bagaimanapun memiliki perbedaan pandangan dengan pinggiran. Sebaliknya, sekuat apapun pinggiran berusaha, upayanya akhirnya tidak berpengaruh dan dijatuhkan oleh pusat.

“Kalau ada, kenapa engkau biarkan dirimu melarat, hingga anak cucumu teraniaya semua. Sedang harta bendamu kaubiarkan orang lain mengambilnya untuk anak cucu mereka. Dan engkau lebih suka berkelahi antara kamu sendiri, saling menipu, saling memeras. Aku beri kau negeri yang kaya raya, tapi kau malas. Kau lebih suka beribadat saja, karena beribadat tidak mengeluarkan peluh, tidak membanting tulang. Sedang aku menyuruh engkau semuanya beramal kalau engkau miskin. Engkau kira aku ini suka pujian, mabuk di sembah saja. Tidak. Kamu semua mesti masuk neraka. Hai, Malaikat, halaulah mereka ini kembali ke neraka. Letakkan di keraknya!" (Navis, 1965: 148)

"Salahkah menurut pendapatmu, kalau kami, menyembah Tuhan di dunia?" tanya Haji Saleh.

“Tidak. Kesalahan engkau, karena engkau terlalu mementingkan dirimu sendiri. Kau takut masuk neraka, karena itu kau taat sembahyang. Tapi engkau melupakan kehidupan kaummu sendiri, melupakan kehidupan anak isterimu sendiri, sehingga mereka itu kucar-kacir selamanya. Inilah kesalahanmu yang terbesar, terlalu egoistis. Padahal engkau di dunia berkaum, bersaudara semuanya, tapi engkau tak mempedulikan mereka sedikit pun." (Navis, 1965:149)

Sementara pada penggalan cerpen Robohnya Surau Kami di atas, Tuhan berkuasa penuh sebagai pusat. Meskipun ia tetap mewajibkan umat-Nya untuk beribadah, nyatanya ibadah yang dimaksudkannya adalah bagaimana manusia selaras dalam memelihara keluarga, lingkungan, masyarakat, dan sumber daya di sekitarnya. Daripada menunjukkan keinginan untuk dihormati dan dipuja terusmenerus, Tuhan digambarkan mampu menilai dengan seadil-adilnya terutama berkenaan dengan kelemahan yang luput dari sorot mata manusia. Hal ini tak urung 
juga membuat gagasan pusat dipertanyakan. Menurut Hutcheon (1988: 58), ini adalah salah satu ciri posmodernisme.

Dalam cerpen Robohnya Surau Kami, Navis mempertanyakan otonomi, kepastian, otoritas, dan lain-lain yang selama ini menjadi perspektif ideal. Bentukbentuk pertanyaan itu terwujud dalam pinggiran/minoritas. Jika selama ini penyerahan penuh dalam bentuk ibadah yang terus menerus kepada Tuhan dianggap sebagai penebus surga di hari akhir, Navis menantang wacana ini dengan memunculkan unsur pusat dan unsur pinggiran. Sebaliknya, Navis memilih menyuarakan pengarang melalui tokoh aku agar mampu menunjukkan kelebihan dan kelemahan masing-masing perspektif akan pusat dan pinggiran tersebut. Pada akhirnya, bagaimanapun juga usaha manusia untuk menuju ke surga, Tuhan adalah kekuatan absolut yang mampu menyelami hati manusia secara lebih dalam.

Hal ini senada dengan salah satu prinsip posmodernisme, yakni pengarang tidak menggerakkan pinggiran untuk menjadi pusat (Hutcheon, 1988:69). Pinggiran hanya dapat mempertanyakan maupun mengkritik pusat. Dalam cerpen Robohnya Surau Kami, unsur-unsur pinggiran muncul sebagai pihak yang mempertanyakan pusat. Kakek yang seumur hidupnya menjadi garin dan selalu berdoa kepada Tuhan sama dengan keberadaan Haji Saleh dan kawan-kawannya, sementara Ajo Sidi yang akhirnya mengubah pandangan Kakek itu sama dengan Tuhan yang menerapkan kontrol dan kuasa penuh terhadap segala sesuatu yang terjadi.

\section{KONTEKSTUALISASI ROBOHNYA SURAU KAMI: CERMIN UMAT BERAGAMA, ARABISASI, DAN NILAI-NILAI SOSIAL SEORANG MUSLIM}

Kontekstualisasi diperlukan dalam teori posmodernisme untuk memenuhi kewajibannya sebagai salah satu penunjuk dengan relevansi masa kini. Hal-hal dinarasikan sesuai dengan kehendak penulis dengan tujuan untuk memuat ideologi yang ingin disampaikannya. Ideologi ini dapat berarti tujuan, maksud, atau cara tertentu yang dapat dipahami melalui kontekstualisasi. Menurut Hutcheon (1988:75), dalam metafiksi historiografi, diperlukan pengondisian karya ke muatan tekstualnya itu sendiri dan pengondisian dengan konteks historis, sosial, dan politik (sebagaimana intertekstualitas) yang lebih luas. Hubungan dengan konteks historis, sosial, dan politik ini diimplikasikan oleh sebagaimana muatan tekstual tersebut terwujud dan dimaksudkan.

Kontekstualisasi membuat fiksi posmodern terhindar dari tujuan nostalgia dan menjadi sebuah karya sastra yang kritis serta bermakna. Sebab dalam ranah teoretis, narasi disadari sebagai struktur buatan manusia, bukan sebagai bentuk yang muncul dengan sendirinya. Baik itu representasi historis atau fiksional, bentuk narasi awal, tengah, dan akhir yang umum menyiratkan proses penstrukturan yang menciptakan makna dan sekaligus tatanan (Hutcheon, 2004: 97).

Cerpen Robohnya Surau Kami karya A. A. Navis memuat gagasan tentang sosial kemasyarakatan sebagai salah satu aspek spiritual dalam diri manusia yang dipertanyakan dalam ranah agama. Dari konteks historisnya, A. A. Navis 
mencerminkan kehidupan rakyat pada masa terbit karya yang dapat direlevansikan dengan masa sekarang.

Sebagai penjaga surau, Kakek tidak mendapat apa-apa. Ia hidup dari sedekah yang dipungutnya sekali se-Jumat. Sekali enam bulan ia mendapat seperempat dari hasil pemungutan ikan mas dari kolam itu. Dan sekali setahun orang-orang mengantarkan fitrah Id kepadanya. Tapi sebagai garin ia tak begitu dikenal. Ia lebih di kenal sebagai pengasah pisau. Karena ia begitu mahir dengan pekerjaannya itu. Orang-orang suka minta tolong kepadanya, sedang ia tak pernah minta imbalan apaapa. Orang-orang perempuan yang minta tolong mengasahkan pisau atau gunting, memberinya sambal sebagai imbalan. Orang laki-laki yang minta tolong, memberinya imbalan rokok, kadang-kadang uang. Tapi yang paling sering diterimanya ialah ucapan terima kasih dan sedikit senyum.

Tapi kakek ini sudah tidak ada lagi sekarang. Ia sudah meninggal. Dan tinggallah surau itu tanpa penjaganya. Hingga anak-anak menggunakannya sebagai tempat bermain, memainkan segala apa yang disukai mereka. Perempuan yang kehabisan kayu bakar, sering suka mencopoti papan dinding atau lantai di malam hari. (Navis, 1965: 140)

Pada masa itu, sulitnya perekonomian Indonesia bahkan tampak pada karyakarya sastranya. Indonesia di tahun 1950-an menjadi cermin indikasi negara berkembang: pertumbuhan ekonomi yang tidak stabil dan tidak meratanya sistem pembangunan sehingga Jakarta sebagai ibukota menarik banyak minat pencari nafkah. Melalui penggalan cerpen Robohnya Surau Kami di Atas, Navis menggambarkan kesenjangan ini dengan menceritakan kondisi kampungnya. Ia menceritakan sosok Kakek yang dapat kita temui sehari-hari dalam kondisi serba kekurangan. Meski demikian, Kakek tak pernah ingin mengejar kesuksesan duniawi, dan sebaliknya ia hidup menyatu dengan surau hingga begitu ia meninggal, surau itu tampak kehilangan pilar penyokong. Pandangan Navis terefleksikan pada tokoh Kakek, di mana surau memegang peranan penting di kampung-kampung kecil yang hidup seadanya. Surau berperan sebagai simbol iman, simbol magis, bahkan simbol pemenuhan fungsi yang dapat beragam sesuai dengan kultur dan ketersediaan sumber daya. Melalui Robohnya Surau Kami, Navis mengungkapkan kegelisahannya tentang bagaimana akhirnya surau-surau yang dulunya demikian terhormat itu akhirnya roboh atau hilang. Ia tak lagi dimaknai sebagai entitas yang suci dan digunakan sesuai fungsi dasarnya, melainkan akhirnya berakhir sebagai onggokan bangunan yang tak bertuan.

Kegelisahan Navis ini bukan tidak beralasan. Di tahun-tahun awal kemerdekaan, gairah politik Indonesia masih berkobar untuk menentukan haluannya. Partai-partai politik yang muncul mati-matian membawa ideologinya masing-masing untuk disebarluaskan di Indonesia hingga tak terhitung berapa ujaran kebencian yang muncul akan suatu golongan. Bagi Navis, sikap ini menunjukkan degradasi manusia, terutama mereka yang mengaku beragama Islam. Sebagai tahun pemilu, 1955 memuat rekam jejak bagaimana politik berhasil menyusupi sendi-sendi masyarakat, bahkan aspek budaya dan agama. Meski tidak mengutarakannya secara eksplisit, Navis berpendapat bahwa hilangnya peran surau yang mengayomi masyarakat dalam makna simbolik itu merupakan akumulasi dari segala bentuk perbuatan manusia yang mulai mengacuhkan sesama dan 
memperjuangkan wacana masing-masing. Pada masa ini, segala sesuatu dipandang sebagai ciri fungsionalitas semata untuk memenuhi kebutuhan manusia.

Hal ini relevan sebab di masa sekarang, Robohnya Surau Kami masih dapat dibaca dan disadari kebenarannya. Ia tidak membuai pembaca pada tujuan nostalgia, melainkan memberikan pemaknaan yang baru sesuai dengan konteks yang tengah terjadi. 2019 sebagaimana tahun pemilu pun dipenuhi dengan ujaran kebencian antargolongan. Surau-surau telah tergantikan masjid-masjid megah yang kekurangan jamaah sehingga keberadaan pusat ritual agama hanya dijalankan secara fungsinya daripada benar-benar menjadi nafas masyarakat di sekitarnya. Meski demikian, hal ini bukan berarti menunjukkan penurunan umat beragama di Indonesia. Sebaliknya, dilansir dari lama berita BBC, Indonesia merupakan negara yang rakyatnya paling mendukung pentingnya agama ${ }^{1}$. Hal ini didukung riset dari Varkey Foundation, sebuah lembaga yang berfokus pada peningkatan standar pendidikan untuk anak-anak terutama dari keluarga miskin, menyatakan bahwa 93 persen warga Indonesia yang berusia 17-23 tahun menganggap agama adalah faktor penting kehidupan yang menentukan kualitas dan kebahagiaan hidup mereka ${ }^{2}$. Pada era sekarang, agama selain berperan sebagai tuntunan hidup, juga dapat menjadi gaya hidup yang menginspirasi banyak orang terutama berkat peran media sosial. Sayangnya hal ini tidak dibarengi dengan keseriusan pemerintah maupun pemuka umat beragama utuk menangkal penyebaran radikalisme dan fanatisme sebagai bentuk penyimpangan kegiatan beragama. Secara lebih lanjut, radikalisme dan fanatisme agama menyebabkan kesenjangan antar umat beragama di Indonesia, terutama jika didukung premis-premis yang dekat dengan kehidupan individu seperti corong ideologi lain yang dianggap sesat, ketimpangan ekonomi, dan gagalnya keadilan sosial. Bahkan, menurut jurnalis Pedersen (2016: 390), upayaupaya yang terkandung dalam peraturan pemerintah dengan tujuan untuk mengurangi kekerasan dan mengukuhkan agama dengan damai tidak berhasil.

Dengan demikian dapat dipahami bahwa pesan yang ingin disampaikan Navis tidak berbatas pada umat Islam semata, tetapi sesuai konteksnya dengan hubungan umat beragama sebagai sesama manusia. Melalui Robohnya Surau Kami, A. A. Navis ingin kembali mengingatkan akan nilai kehidupan manusia yang seyogyanya saling menjaga, saling melindungi, dan saling mengayomi satu sama lain laiknya peran surau pada masa itu.

"Sedari muda aku di sini, bukan? Tak kuingat punya isteri, punya anak, punya keluarga seperti orang lain, tahu? Tak kupikirkan hidupku sendiri. Aku tak ingin cari kaya, bikin rumah. Segala kehidupanku, lahir batin, kuserahkan kepada Allah Subhanahuwataala. Tak pernah aku menyusahkan orang lain. Lalat seekor enggan aku membunuhnya. Tapi kini aku dikatakan manusia terkutuk. Umpan neraka. Marahkah Tuhan kalau itu yang kulakukan, sangkamu? Akan dikutukinya aku kalau selama hidupku aku mengabdi kepada-Nya? Tak kupikirkan hari esokku, karena aku yakin Tuhan itu ada dan pengasih dan penyayang kepada umatnya yang tawakal.

\footnotetext{
1 https://www.bbc.com/indonesia/majalah/2014/04/140417_majalah_agama_peran

2 Artikel Sattwika Duhita berjudul “Alasan Generasi Z Indonesia Paling Fanatik Beragama Dibanding Negara Lain" yang dimuat dalam Vice Indonesia 30 Mei 2018

https:/www.google.com/amp/s/www.vice.com/amp/id_id/article/bj3vew/alasan-generasi-zindonesia-paling-fanatik-beragama-dibanding-negara-lain
} 
Aku bangun pagi-pagi. Aku bersuci. Aku pukul beduk membangunkan manusia dari tidurnya, supaya bersujud kepada-Nya. Aku sembahyang setiap waktu. Aku pujipuji Dia. Aku baca Kitab-Nya. Alhamdulillah kataku bila aku menerima karunia-Nya. Astagfirullah kataku bila aku terkejut. Masya Allah kataku bila aku kagum. Apa salahnya pekerjaanku itu? Tapi kini aku dikatakan manusia terkutuk." (Navis, 1965:142-143)

Nilai yang ingin disampaikan Navis tersebut tampak eksplisit pada penggalan cerpen di atas. Melalui tokoh Kakek, Navis memberikan ruang bagi orang-orang yang mengagungkan agama dengan cara yang dianggapnya 'kurang benar'. Bagi orang-orang itu, kehidupan yang diberikan Yang Maha Kuasa seyogyanya dikembalikan dengan cara mengabdi sepenuh hati: selalu memuji-muji Tuhan sepanjang waktu tanpa mengurus kepentingan duniawi. Jika ditulusuri lebih lanjut, apa yang diungkapkan tokoh Kakek di atas sama dengan rasa pamrih. Banyak orang beragama, yang dicerminkan melalui tokoh Kakek, rajin berdoa dan memuja Tuhan karena berharap akan masuk surga. Orang-orang seperti ini menghayati betul segala tata cara beribadah kepada Tuhan, seperti mengikuti perintah-Nya dan menjauhi larangan-Nya.

Pada masa sekarang, ketaatan sedemikian rupa perlu diiringi dengan kebijakan berperilaku. Pada penggalan cerpen di atas, Kakek berkata bahwa ia mengekspresikan segala perasaannya sebisa mungkin dalam bahasa Arab. Meski frasa-frasa tersebut lazim diucapkan umat muslim sehari-hari, namun kecenderungan Kakek dengan menganggap bahwa hal tersebut merupakan kewajiban adalah salah satu dari bentuk arabisasi. Arabisasi merupakan pertumbuhan budaya Arab pada populasi non-Arab, dalam hal ini umat Islam sebagai pemeluk agama yang teks-teks rujukannya mayoritas menggunakan bahasa $\mathrm{Arab}^{3}$. Arab sebagai tradisi dengan Islam sebagai ajaran agama adalah dua hal yang berbeda ${ }^{4}$. Sebagai sebuah bangsa, tradisi Arab tentu dipengaruhi oleh manusia, lingkungan hidup, dan kulturnya yang berbeda dari Indonesia. Berdasarkan landasan etnografi tersebut, Navis menganjurkan kita untuk bisa memahami perbedaan ini dan bijak dalam menyikapi masuknya budaya-budaya luar di Indonesia.

"Kalau ada, kenapa engkau biarkan dirimu melarat, hingga anak cucumu teraniaya semua. Sedang harta bendamu kaubiarkan orang lain mengambilnya untuk anak cucu mereka. Dan engkau lebih suka berkelahi antara kamu sendiri, saling menipu, saling memeras. Aku beri kau negeri yang kaya raya, tapi kau malas. Kau lebih suka beribadah saja, karena beribadah tidak mengeluarkan peluh, tidak membanting tulang. Sedang aku menyuruh engkau semuanya beramal kalau engkau miskin. Engkau kira aku ini suka pujian, mabuk di sembah saja. Tidak. Kamu semua mesti masuk neraka. hai, Malaikat, halaulah mereka ini kembali ke neraka. Letakkan di keraknya!" (Navis, 1965:148)

Pandangan Navis tampak secara eksplisit pada representasi dirinya dalam tokoh Tuhan yang dapat dilihat pada penggalan cerpen di atas. Bagi Navis, kegigihan manusia untuk berdoa sepanjang waktu tidak ada gunanya apabila tidak peduli terhadap lingkungan dan sesama. Hal ini bukan semata-mata murni

\footnotetext{
${ }^{3} \mathrm{https} / /$ en.m.wikipedia.org/wiki/Arabization

${ }^{4}$ Artikel Dedik Priyanto berjudul "Salah Kaprah Arabisasi Islam Indonesia" di laman Islami.co pada 7 Januari 2018 https://islami.co/salah-kaprah-arabisasi-islam-indonesia/
} 
pandangan Navis, melainkan juga telah dianjurkan oleh Islam dengan dalil hablum minallah wa hablum minannas yang berarti menjaga hubungan dengan Allah dan menjaga hubungan dengan sesama manusia ${ }^{5}$. Sejatinya, tingkat keimanan manusia tidak semata diukur dari kuantitas ibadah berupa doa dan puji-pujian semata, tetapi juga ibadah sebagai bentuk bakti diri terhadap lingkungan dan sesamanya.

Yang tak dapat dihindarkan dalam setiap penelitian fiksi posmodern adalah bagaimana menemukan hubungan dengan konteks yang signifikan (Hutcheon, 1988: 82). Menurut van Dijk (dalam Hutcheon, 1988:82), teks-teks posmodern mengarahkan pembaca untuk mempertimbangkan wacana atau bahasa yang digunakan. Di dalamnya, wacana dikontekstualisasikan sebagai modus interaksi dalam situasi sosial budaya yang sangat kompleks (Meidiana, 2016:18). Cerpen Robohnya Surau Kami karya A. A. Navis memberikan perspektif yang berbeda dari aspek intra agama itu sendiri, yang di dalamnya tidak hanya diatur tata cara beribadah melalui doa, tetapi juga menganjurkan manusia untuk menyayangi sesama dan merawat lingkungannya. Pada masa sekarang, maksud yang ditujukan oleh A. A. Navis cukup beragam dalam berbagai lini kehidupan. Baru-baru ini kita mendapati fenomena Kementerian Agama RI yang dilanda badai korupsi dalam bentuk penyelewengan dana pengadaan kitab suci, penolakan terhadap budaya sendiri dan digantikan oleh gaya hidup kearab-araban, maupun sentimen antarumat beragama yang menghasilkan bentrok maupun kericuhan di berbagai daerah. Meski tidak secara langsung menyindir dan menentang wacana-wacana ini, media karya sastra yang digunakan Navis dapat memuat identifikasi situasi masyarakat (sosial, politik, budaya, dll) ketika karya tersebut diproduksi serta kesinambungan dan relevansinya dengan masa karya tersebut dipahami/dibaca, yakni masa kini.

Hal ini senada dengan pendapat Hutcheon (1988: 80) yang menyatakan bahwa fiksi posmodern tidak membatasi investigasi pada pembaca dan teks semata, tetapi juga proses produksi karya tersebut. Dalam proses produksi tersebut, motif dan tujuan penulis akan memperkuat relevansi karya. Dalam cerpen Robohnya Surau Kami, misalnya, A. A. Navis secara kontinu mempresentasikan gagasannya tentang ketimpangan akhlak orang-orang yang mengaku beragama, terutama muslim. Berkenaan dengan hal tersebut, Hutcheon (1988: 75) berpendapat sebagai berikut.

The self-conscious theorizing and historicizing of theory by writers such as Edward

Said, Terry Eagleton, Teresa de Lauretis, Frank Lentricchia, and, of course, Michel Foucault, have been working in much the same manner as have contemporary art forms such as historiographic metafiction: both have foregrounded the need to break out of the still prevailing paradigms - formalist and humanist-and to-situate both art and theory in two important contexts. They must be situated, first, within the enunciative act itself, and second, within the broader historical, social, and political (as well as intertextual) context implied by that act and in which both theory and practice take root.

Kecenderungan yang dilakukan oleh penulis-penulis besar lainnya dalam penulisan metafiksi historiografis ialah memosisikan karya maupun teori dalam dua konteks penting: pengondisian karya dalam tindak aplikasinya dan pengondisian

\footnotetext{
${ }^{5}$ Tulisan Zulman berjudul "Hablum Minallah wa Hablum Minannas" dalam https://bdkpadang/kemenag.go.id/index.php?option=com.content\&view=artikel\&id=713:zulmanagust us\&catid $=41$ :top-headlines\&ltemid $=158$
} 
karya dengan konteks historis, sosial, dan politis yang diimplikasikan dalam karya tersebut. Dengan demikian, fiksi posmodern selain menitikberatkan pada substansinya sebagai karya sastra, juga memiliki keterkaitan yang erat dengan situasi yang lebih luas. Dalam hal ini, cerpen Robohnya Surau Kami karya A. A. Navis mampu memosisikan karya dengan kondisi saat ini.

\section{SIMPULAN}

Analisis ini menyimpulkan bahwa Robohnya Surau Kami adalah sastra religi yang dapat dikaji dari perspektif posmodern. Kajian itu menunjukkan bahwa Robohnya Surau Kami adalah termasuk fiksi posmodern. Ia tidak menunjukkan representasi otomatis maupun sebatas usaha-usaha deskriptif saja, namun juga kritis dalam relasi ironinya terhadap masa lalu maupun masa depan. Hal ini ditunjukkan melalui pemilihan sudut pandang, struktur kebakuan referensi, dan kemampuannya untuk tidak terikat pada ruang temporal.

Sebagai fiksi posmodern, Robohnya Surau Kami memuat unsur-unsur berupa fakta cerita, pusat dan pinggiran, serta kontekstualisasi. Fakta cerita Robohnya Surau Kami memuat interdiskursivitas dengan kajian-kajian keagamaan, terutama Alquran pada ayat-ayat tentang hari akhir, surga, dan neraka. Pusat dalam cerpen Robohnya Surau Kami direpresentasikan oleh tokoh Ajo Sidi dan Tuhan. Tokoh aku yang berperan sebagai narator pun sedikit banyak menunjukkan persetujuannya terhadap pandangan tokoh-tokoh pusat tersebut. Sementara pinggiran dalam cerpen ini ditunjukkan oleh tokoh Kakek dan Haji Saleh. Keberadaan tokoh pinggiran adalah sebagai unsur yang mempertanyakan pusat; baik perilaku, kebijakan, bahkan eksistensinya. Namun tetap tidak bisa menggerakkan pusat. Kontekstualisasi cerpen Robohnya Surau Kami menghasilkan relevansi dengan tiga isu pada masa kini, yakni sebagai cermin situasi dan kondisi umat beragama yang dipenuhi kesenjangan akibat berbagai faktor kehidupan, maraknya arabisasi yang bahkan mampu menggerus identitas kenusantaraan, dan meneguhkan kembali nilai-nilai yang selayaknya dimiliki oleh seorang muslim dengan tidak meninggalkan ibadah maupun sosialnya-sebaliknya, merawat kehidupan sosial pun termasuk dalam ibadah-.

Dengan demikian dapat dipahami bahwa menelaah Robohnya Surau Kami dengan teori posmodernisme menunjukkan bahwa pelajaran penting dari posmodernisme adalah perlunya penelitian yang lebih dari sekadar teks dan pembaca untuk mengaktifkan proses pemberian makna atas suatu karya agar apa yang disampaikan dalam karya tersebut mendapat pelekatan makna yang sebenarbenarnya. 


\section{DAFTAR PUSTAKA}

Faruk. 2015. Pengantar Sosiologi Sastra. Yogyakarta: Pustaka Pelajar.

Goodman, Paul. 1977. Creator Spirit Come! The Literary Essay of Paul Goodman. New York: E.P. Dutton.

Herfanda, Ahmadun Yosi. 2008. Sastra sebagai Agen Perubahan Budaya. Dalam Anwar Efendi (Ed.). 2008. Bahasa dan Sastra dalam Berbagai Perspektif. Hlm. 132. Yogyakarta: Tiara Wacana.

Heryanto, Ariel. 2018. Identitas dan Kenikmatan. Jakarta: Kepustakaan Populer Gramedia.

Hutcheon, Linda. 1988. A Poetics of Posmodernism. London: Routledge.

2004. Politik Posmodernisme Linda Hutcheon. Terjemahan oleh Apri Danarto dari Politics of Posmodernism (1989). Yogyakarta: Jendela.

Kuntowijoyo. 2006. Budaya dan Masyarakat. Yogyakarta: Tiara Wacana.

Mangunwijaya, Y. B. 1982. Sastra dan Religiositas. Jakarta: Sinar Harapan.

McHale, Brian. 1991. Postmodernist Fiction. London: Routledge.

Miola, Robert S. 2004. "Seven Types of Intertextuality". Dalam Michele Marrapodi (Ed.). 2004. Shakespeare, Italy, and Intertextuality. Hlm. 13-25. New York: Manchester University Press.

Pedersen, Lene. 2016. "Religious Pluralism in Indonesia". Dalam The Asia Pacific Journal of Anthropology Volume 17 (387-398). 2016.

Prihatmi, Th. dan Sr. Rahayu. 1999. "Gerakan yang Merongrong Tradisi Realisme: Makna dan Fungsinya". Pidato ini disampaikan pada acara pengukuhan jabatan Guru Besar dalam ilmu kesusasteraan Indonesia Modern di Fakultas Sastra Universitas Diponegoro. Semarang: Tidak Diterbitkan.

Pujiharto. 2010. Pengantar Teori Fiksi. Yogyakarta: Elmatera.

Sarup, M. 2003. Poststrukturalisme dan Posmodernisme: Sebuah Pengantar Kritis. Terjemahan oleh Medhy Aginta Hidayat dari An Introductory Guide to PostStructuralism and Postmodernism. Yogyakarta: Jendela.

Teeuw, A. 1988. Sastra dan Ilmu Sastra Pengantar Teori Sastra. Jakarta: Pustaka Jaya.

Wellek, Rene dan Austin Warren. 1990. Teori Kesusastraan. Terjemahan oleh Melanie Budianta dari Theory of Literature. Jakarta: Gramedia.

White, Edward. 1972. The Pop Culture Tradition: Readings with Analysis for Writing. New York: W.W. Norton and Company, Inc. 


\section{Daftar Laman}

Duhita, Sattwika. 2018. Alasan Generasi Z Indonesia Paling Fanatik Beragama Dibanding NegaraLain.

https://www.google.com/amp/s/www.vice.com/amp/id_id/article/bj3vew/alas an-generasi-z-indonesia-paling-fanatik-beragama-dibanding-negara-lain.

Diakses pada 13 Juni 2019.

Priyanto, Dedik. 2018. Salah Kaprah Arabisasi Islam Indonesia. https://islami.co/salahkaprah-arabisasi-islam-indonesia/. Diakses pada 13 Juni 2019.

Zulman. Hablum Minallah Hablum Minannas. https://bdkpadang/kemenag.go.id/index.php?option=com.content\&view=artik el\&id=713:zulmanagustus\&catid=41:top-headlines\&ltemid=158. Diakses pada 28 Mei 2019.

https://www.bbc.com/indonesia/majalah/2014/04/140417_majalah_agama_peran 